\title{
Globalisasi Ekonomi Syariah di Indonesia dan perannya terhadap UMKM
}

\author{
Sumitro \\ AMIK Labuhanbatu \\ e-mail : sumitro.ulb@gmail.com
}

\begin{abstract}
Indonesia has a very big role in the struggle for the implementation of Islamic economics globally. Although the empowerment of SMEs that are proven to anticipate the crisis has not been fully implemented with the maximum and management of natural resources have not been exploited specifically. Indonesia's dependence on foreign debt increase the budget deficit, assuming other factors remain unchanged, because the expenditure for the payment of principal and interest on loans the central government expenditure is higher than revenue. State sukuk important as Islamic financial growth driver as a reference for the private sector to issue sukuk and investment instruments for financial institutions to have additional liquidity, but also used by Bank Indonesia as an instrument of open market operations in this practice in accordance with the SME sector business climate
\end{abstract}

Keyword: Globalization, Islamic Economics, SMEs

\section{Introduction}

Globalisasi merupakan sebuah proses multi-dimensi yang menuntut konsistensi dan terintegrasi dengan ekonomi, politik, sosial, budaya dan ideologi (Al-Rodhan \& Stoudmann, 2006). Fenomena globalisasi terwujud dalam bentuk penyempitan waktu dan ruang dalam hubungan sosial (Harvey, 1990). Hubungan sosial antara individu dengan masyarakat maupun antar masyarakat dalam suatu negara bahkan antar negara menjadi transparan dan tidak mengenal batas-batas politik (Delanty \& Rumford, 2007). Perkembangan yang begitu cepat dalam teknologi informasi, perdagangan internasional, mobilitas tenaga kerja, modal dan keuangan antar negara telah mengakibatkan peran ekonomi suatu negara terhadap perekonomian global menjadi semakin kurang berarti (Berger \& Huntington, 2003). Proses ini telah mempengaruhi konstruk sistem sosial masyarakat yang telah terbangun selama ini (Inda \& Rosaldo, 2002). Proses globalisasi memiliki pengaruh yang sangat besar bagi perkembangan nilai-nilai agama sebagai sebuah pandangan yang memberikan pengaruh yang besar bagi masyarakat (Basir \& Mamat, 2012). Pentingnya peran agama dalam kehidupan sosial politik masyarakat sangat diperlukan untuk memproses dampak negarif dari globalisasi tersebut yang dapat merubah pola hidup ataupun budaya seseorang sehingga diperlukan nilai-nilai universal tentang toleransi, kebersamaan, keadilan, kesatuan, musyawarah dan lainnya (Khotimah, 2009). Globalisasi bersifat sekularistik, materialistik dan liberalalisasi yang selalu menjunjung tinggi kebebasan berpendapat dan melakukan sesuatu sesuai hak asasinya. Dikarenakan sifatnya, globalisasi telah memiliki mekanisme yang dapat memasuki semua lini kehidupan masyarakat, berbangsa dan bernegara dalam betuk ideologi sebagai tatanan ekonomi dunia. Ideologi baru inilah yang membonceng globalisasi dan itu adalah Neo-liberal. Ketidakmerataan distribusi pendapatan, kekayaan sebagai pemicu utama gejolak sosial dan pengurasan sumber-sumber daya alam yang tidak bisa diperbaharui telah menjadi sebuah penyakit ekonomi yang serius bagi kelangsungan peradaban umat manusia (Pangiuk, 1997). Skenario ekonomi yang ditandai oleh persaingan, efisiensi, pragmatisme dan keterbukaan menimbulkan suatu kemungkinan baru untuk mencoba mengajukan alternatif disiplin keilmuan sosial pada sistem ekonomi yang didasarkan pada nilai-nilai dan ajaran diluar dari sistem ekonomi konvensional yaitu sistem ekonomi Islam (syari'ah). Pembicaraan alternatif keilmuan tersebut menjadi isu yang dramatis akan keyakinan yang menimbulkan bahwa ekonomi islam dapat mengatasi permasalahan-permasalahan ekonomi yang dilahirkan oleh sistem ekonomi konvensional ((Pryor (1985), Cizakca (2007), Kuran (1986), Sharif (2003), Sattar (1989), A. 
Dimyati (2007)). Pada tanggal 31 Desember 2015 bangsa-bangsa dikawasan Asia Tenggara atau lebih dikenal dengan ASEAN akan memasuki era baru dalam hubungan perekonomian khususnya perdagangan dalam bentuk Masyarakat Ekonomi Asean (MEA)("Asean Economic Community Blueprint," 2008). Siap atau tidak siap semua negara dikawasan ASEAN sudah harus meleburkan batas teritorial negaranya dalam satu pasar bebas yang diperkirakan akan menjadi tulang punggung perekonomian dikawasan Asia setelah China. Semua industri tidak terkecuali industri keuangan dan perbankan syariah akan berkompetisi dalam pasar besar MEA (Alamsyah, 2012). Industri keuangan dan perbankan syariah nasional, regulator, praktisi, kalangan industri dan para akademisi harus bersinergi untuk menjadikan tantangan besar ini menjadi peluang bagi kemajuan perekonomian nasional. Sebagaimana diketahui, bahwa sistem ekonomi syariah atau ekonomi Islam merupakan sistem ekonomi yang berlandaskan syariah Islam. Disebutkan dalam Al-Qur'an pada surat Al Jaatsiyah ayat 18, Allah berfirman : Kemudian Kami jadikan kamu berada di atas suatu syariat (peraturan) dari urusan (agama itu), maka ikutilah syariat itu dan janganlah kamu ikuti hawa nafsu orang-orang yang tidak mengetahui (45:18). Ibn al-Qayyiln mengatakan "The basis of the Shari'ah is wisdom and welfare of the people in this world as well as the Hereafter. This welfare lies in complete justice. mercy. well-being and wisdom. Anything that departs from justice to oppression. From mercy to harshness. from welfare to misery and from wisdom to folly. has nothing to do with the Shari'ah" and al-Ghazal mengatakan "The very objective of the Shari'ah is to promote the welfare of the people. which lies in safeguarding their faith. their life. their intellect. their posterity and their wealth. Whatever ensures the safeguarding of these five serves public interest and is desirable" (Chapra, 1992); disini terlihat bahwa tujuan ekonomi syariah adalah membawa keadilan untuk mencapai sebuah tujuan sedangkan dalam tatanan globalisasi ekonomi pada konteks neo-liberal hal ini selalu dipertanyakan namun negara-negara islam tidak bisa terlepas dari pekembangan ekonomi yang telah menglobal, untuk itulah diperlukan sebuah kerangka untuk mengantisipasi globalisasi dengan metode keislaman yang membawa unsur keadilan dalam berekonomi (Chapra, 2001). Kegagalan pemerintah Indonesia pada ASEAN China Freetrade Agreement (ACFTA) diharapkan tidak terulang pada Masyarakat Ekonomi Asean (Ariawan, 2012), tidak ada salahnya untuk melakukan penyesuaian, kita dapat belajar dan melihat negara Cina dalam menunggangi globalisasi sebagaimana pemerintahnya melakukan upaya-upaya yang positif untuk meningkatkan, mendampingi dan menyalurkan produk-produk bangsanya hingga mampu bersaing di dunia luar sebelum pemberlakuan ACFTA dan AFTA. Indonesia memiliki nilai-nilai kegotongroyongan yang menjadi menjadi perekat dan pemersatu kekuatan ekonomi bangsa. Nilai ini secara substantif, ekuivalen dengan prinsip ekonomi syariah yang sedang menggeliat dalam beberapa tahun terakhir dan di Indonesia, ekonomi syariah tumbuh pesat dalam beberapa tahun ini karena sejalan dengan nilai kegotongroyongan yang dimilik bangsa Indonesia (Zulaikha, 2013). Nilai ini tidak jauh berbeda dengan konsep ekonomi dan bisnis syariah yang mengutamakan kemaslahatan dan kebaikan bersama. Mengingat kembali ucapan dari Menteri Koordinator Perekonomian Hatta Rajasa dalam sambutan The 2th Islamic Economics and Finance Research Forum di Universitas Islam Negeri (UIN) Syarif Hidayatullah, Ciputat, Tangerang, Banten; "bahwa semakin tinggi tuntutan keadilan, tuntutan penurunan kemiskinan global, tuntutan meningkatan kualitas kehidupan umat manusia dan yang harus diperhatikan indonesia adalah dunia tengah merumuskan tataran ekonomi global, untuk mendorong pertumbuhan ekonomi yang tinggi, keseimbangan, dan berkelanjutan serta poin yang terakhir adalah sekitar 23\% penduduk di dunia merupakan umat islam yang tersebar diberbagai macam negara, yang akan memberikan kontribusinya kepada perekonomian dunia melalui konsep ekonomi syariah" (Deny, 2013). Menindaklanjuti ucapan Menteri Koordinator Perekonomian Hatta Rajasa tersebut terlihat jelas pada Laporan Thomson Reuters pada "State of the Global Islamic Economy 2014 - 2015 Report", bahwa Indonesia masih berada pada posisi No. $10(33,8 \%)$ dalam penilaian Global Islamic Economic Indicator (State of the Global Islamic Economy 2014 - 2015 Report, 2015), bahwa posisi pertama adalah Malaysia dengan GIEI 111,5 \%, disusul oleh 
United Arab Emirates sebesar 71,6 \% dan posisi terakhir adalah Australia sebesar $27,5 \%$ dan posisi Indonesia diurutan 10 diatas brunei dan dibawah pakistan. Hal ini kalau dikaitkan dengan geografis sangatlah tidak etis, mengingat bahwa Indonesia adalah penduduk Islam terbesar di dunia. Hanya dua sektor dari penilaian diatas yang masuk dalam kategori 10 besar dimana Indonesia menempati urutan ke 8 untuk obatobatan dan kosmetik, dan urutan ke 10 untuk keuangan, sementara untuk kategori media \& recreation, Fashion, Travel dan Halal Food, Indonesia tidak masuk dalam kategori rangking 10 besar. Padahal dalam Kawasan ASEAN dan melihat negara-negara lainnya terhadap penilaian dari Indikator tersebut, Indonesia berada di posisi kedua setelah Malaysia, tetapi persentase ketertinggalan Indonesia cukup tinggi yaitu sebesar 77,7 persent. Tantangan ini bertambah ketika Presiden Joko Widodo membeberkan peluang yang bisa diraih para investor dalam APEC CEO Summit di Beijing (Nrm, 2014). Jika pengembangan ekonomi syariah diprioritas sebagai salah satu pilar strategis pembangunan, Indonesia berpotensi sebagai negara produsen dari pada negara tujuan pasar (Mashdurohatun, 2011). Pendasaran ini dapat diuraikan; pertama, Populasi penduduk muslim yang terbesar memberikan peluang bagi perkembangan industri keuangan syariah di Indonesia; kedua, Indonesia berpotensi menjadi supplier makanan halal bagi negara-negara muslim dunia; ketiga, Industri busana muslim Indonesia mampu bersaing dan berkembang pesat yang berpotensi menjadi kiblat mode muslim dunia; Keempat, Besarnya potensi pariwisata yang belum tergali dapat menjadikan Indonesia sebagai negara tujuan; kelima, begitu juga dengan pasar rekreasi dan media nya sangat berhubungan dengan pariwisata; keenam, Obat-obatan dan pasar kosmetik juga sangat berpotensi mengingat tingginya kebutuhan obat dan kosmetik dunia dimana Indonesia memiliki bahan-baku dari keragamanan tumbuhtumbuhan dan hewani dan warisan budaya yang ada di Indonesia (Peran Ekonomi Syariah Dalam Kebijakan Ekonomi Nasional Untuk Menghadapi $A E C$, 2014). Sementara itu, Perkembangan ekonomi syariah di Indonesia akhir-akhir ini menunjukkan hukum atau syariat Islam sebagai hukum yang hidup di negeri ini dengan didukung oleh masyarakat melalui para pelaku ekonomi, lembaga-lembaga keuangan, pendidikan, keulamaan, peradilan dan penyelesaian sengketa alternatif dan lain-lain belum efektif dilakukan. Gejala ini juga menunjukkan penyerapan lembaga-lembaga masyarakat terhadap syariat Islam sebagai tuntunan hukum mereka, walaupun peraturan perundangundangan dalam bidang ekonomi syariat masih sangat terbatas, namun di pihak lain menunjukkan kelambanan legislator Indonesia dalam mengantisipasi keinginan dan kebutuhan masyarakat yang mendesak (Ja'far, 2010). Ekonomi Syariah dapat memperkuat pasar dengan mendekatkan sektor makro malalui Jizyah, Zakat melalui baitul mal dan sektor mikro dengan muamalah serta penerapan nilai-nilai islam secara komprehensif dalam kehidupan manusia. Rule of the game dalam menjalankan perekonomian pun diatur dengan jelas, baik formal rule (berlandaskan al-quran dan hadits) yang berdampingan dengan informal rule (nilai-nilai, dan norma-norma masyarakat Indonesia yang berdasarkan kegotongroyongan) yang tidak bertentangan dengan sistem ekonomi Pancasila. Sehingga sangat memungkinkan jika perkonomian Indonesia dapat menerapkan prinsip ekonomi syariah yang mengharamkan Riba, Judi, Dholim (aniaya), Gharar (penipuan), Barang Haram, Maksiat, Risywah (suap) dan prinsip bagi hasil yang terbukti lebih menguntungkan untuk mencapai kemaslahatan hidup orang banyak serta membentengi Indonesia dari ekonomi liberal dalam tataran globalisasi. Lahirnya Undang-Undang No 3 tahun 2006 tentang Perubahan atas Undang-Undang No 7/1989 tentang Peradilan Agama yang mengatur harta benda, bisnis dan perdagangan secara luas terlihat pada pasal 49 point $\mathrm{i}$ (Undang-Undang Republik Indonesia Nomor 3 Tahun 2006 Tentang Perubahan Atas UndangUndang Nomor 7 Tahun 1989 Tentang Peradilan Agama, 2006) yang kemudian dilakukan perubahan yang kedua pada tahuan 2009 (Undang-Undang Republik Indonesia Nomor 50 Tahun 2009 Tentang Perubahan Kedua Atas Undang-Undang Nomor 7 Tahun 1989 Tentang Peradilan Agama, 2009) disebutkan dengan jelas bahwa Pengadilan Agama bertugas dan berwenang memeriksa, memutus dan menyelesaikan perkara di tingkat pertama antara orang-orang yang beragama Islam di 
bidang ekonomi syariah. Undang-Undang tersebut menyebutkan bahwa yang dimaksud dengan ekonomi syariah adalah perbuatan atau kegiatan usaha yang dilaksanakan menurut prinsip syari'ah, antara lain meliputi; a). Bank syariah, b). Lembaga keuangan mikro syari'ah, c). asuransi syari'ah, d). reasurasi syari'ah, e). reksadana syari'ah, f). Obligasi syariah dan surat berharga berjangka menengah syari'ah, g). Sekuritas syari'ah, h). Pembiayaan syari'ah, i). Pegadaian syari'ah, j). dana pensiun lembaga keuangan syari'ah dan k). bisnis syari'ah. Dalam prakteknya, sebelum amandemen UU No $7 / 1989$, penegakkan hukum kontrak bisnis di lembaga-lembaga keuangan syariah tersebut mengacu pada ketentuan KUH Perdata yang merupakan terjemahan dari Burgerlijk Wetboek (BW), kitab Undang-undang hukum sipil Belanda yang dikonkordansi keberlakuannya di tanah Jajahan Hindia Belanda sejak tahun 1854, sehingga konsep perikatan dalam Hukum Islam tidak lagi berfungsi dalam praktek formalitas hukum di masyarakat, tetapi yang berlaku adalah Burgerlijk Wetboek (BW). Ketika wewenang mengadili sengketa hukum ekonomi syariah menjadi wewenang absolut hakim pengadilan agama, maka dibutuhkan adanya kodifikasi hukum ekonomi syariah yang lengkap agar hukum ekonomi syariah memiliki kepastian hukum dan para hakim memiliki rujukan standart dalam menyelesaikan kasus-kasus sengketa di dalam bisnis syari'ah (Budianto, 2013). Dalam bidang perkawinan, warisan dan waqaf, Indonesia telah memiliki KHI (Kompilasi Hukum Islam), sedangkan dalam bidang ekonomi syariah Indonesia belum memilikinya. Kedudukan KHI secara konstitusional, masih sangat lemah, karena keberadaannya hanyalah sebagai Inpres. Karena itu, dibutuhkan suatu aturan hukum yang lebih kuat yang dapat menjadi rujukan para hakim dalam memutuskan berbagai persoalan hukum. Secara teoritis penerapan Kodifikasi Hukum Ekonomi Syariah di Indonesia dapat terwujud melalui peran penting pemerintah dalam 'Political Will' Penguasa, sebagaimana telah diterapkan pada Kompilasi Hukum sebelumnya, (Sufiarina (2011), Hasnita (2012), Kersten (2012)). Langkah lain yang perlu juga diambil adalah mendirikan Lembaga Fatwa Negara dengan meningkatkan status DSN/Mejelis Fatwa MUI menjadi Lembaga Fatwa Negara berdasarkan undang-undang dengan kedudukan sejajar sehingga mempunyai kekuatan yang sama.

\section{Literature}

\section{A. Indonesia and Economy Global World}

Pada Tahun 2014 yang lalu diperkiraan pertumbuhan untuk Asia sebesar 5,5\% dan Indonesia sebesar 5,4 \%, dan dianggap adanya perkiraan perlambatan dari dampak kebijakan pengetatan pada pertumbuhan investasi dan defisit transaksi berjalan yang diramalkan mengecil hingga sebesar 3,0\% dari PDB pada 2014 dari 3,3\% dari PDB tahun sebelumnya, dengan harapan inflasi diramalkan turun menjadi $5,5 \%$ dan berlanjut menuju pengurangan ketidakseimbangan mikro serta stabilitas keuangan (Cowen, 2015) ; ternyata jauh dari perkiraan, dimana GDP real 2014 hanya sebesar 5 \%. Pada Tahun berjalan 2015 menjelang aktifnya pelaksanaan globalisasi ekonomi dalam konteks MEA akhir Desember yang menunjukkan bahwa pertumbuhan PDB riil Indonesia turun menjadi $4,7 \%$ dari data tertanggal 5 Mei (Deorukhkar \& Xia, 2015) dari tahun ke tahun di Q1, Hal ini mengindikasikan bahwa Pemerintahan yang dipimpin oleh presiden Joko Widodo (Jokowi) mengalami penurunan pertumbuhan $3 \%$ dari GDP Real 2014. Hal ini memantik tekanan terhadap indikator ekonomi seperti menurunnya nilai tukar rupiah yang memberikan ketidakpastian terhadap pelaku pasar akibat dari kinerja pemerintah ("Rombak Kabinet Bangkitkan Pasar," 2015), hal senada diungkapkan oleh para pengusaha Indonesia yang berharap kepada pemerintah agar mengubah pandangan pasar untuk membangkitkan kepercayaan yang diakibatkan dari kinerja pemerintah karena defisit transaksi berjalan dengan inflasi 7,15\% diatas $5 \%$ dari asumsi APBN-P (Mahendra, 2015). Sementara pertumbuhan Indonesia pada ASIA Real GDP dapat dilihat dalam Regional Economic Outlook Asia and Pacific: Stabilizing and Outperforming Other Regions, (2015) bahwa ada kenaikan $2 \%$ dari tahun 2014 dan diprediksi menaik $3 \%$ pada tahun 2016, namun diference dari oktober 2014 World Economy Outlook, ada penuruan sebesar $2 \%$ pada tahun 2015 dan tetap -0,3 \% pada tahun 2016. Hal mengindikasikan bahwa pertumbuhan ekonomi Indonesia secara global pada skala di asia berdasarkan Outlook keseluruhan pada prospek 
perekonomian Asia dan Pasifik masih tetap baik. Walaupun, Pertumbuhan kawasan Asia dan Pasifik diperkirakan akan tetap stabil pada 5,6 persen di tahun 2015 dan akan menurun sedikit menjadi 5,5 persen untuk 2016. Turunnya Harga minyak pada level yang lebih rendah memang memberikan kesempatan bagi pemerintah Indonesia untuk mereformasi subsidi energi dan pajak, hal ini terlihat dengan keluarnya isu kebijakan tentang rencana penghilangan pajak NJOP dan rencana penggantian premium. Melalui deregulasi harga solar dan peningkatan energi cukai. Penghapusan subsidi energi umum digunakan untuk menstransfer defisit anggaran yang lebih rendah dan menjadi relevan. Sedangkan reformasi untuk meningkatkan pendidikan, tenaga kerja dan pasar produk dalam negeri serta kemudahan batas-batas perdagangan serta investasi dipercaya dapat meningkatkan produktivitas dengan dukungan prospek pertumbuhan kondisi bisnis Indonesia selanjutnya (Stavrev et al., 2015). Sedangkan pada World Economic Outlook: Uneven Growth-Short- and Long-Term Factors, (2015) diperkiraan pertumbuhan Indonesia dari 5,2 persen tahun ini secara luas sejalan dengan pertumbuhan tahun lalu. Pada Skala Asia Tenggara, pertumbuhan Indonesia diperkirakan akan tetap banyak berubah pada tahun 2015 (meskipun ini lebih rendah dari proyeksi sebelumnya), tetapi meningkat pada tahun 2016 atas reformasi yang dilaksanakan dan untuk negara Asean lainnya seperti Malaysia diperkirakan melambat tahun ini (4,8 persen) dan Prospek Thailand yang diperkirakan akan memperbaiki kejelasan lebih besar pada kebijakan jangka pendek, dan pertumbuhan di Filipina telah direvisi naik menjadi 6,7 persen pada tahun 2015 menjadi pembanding untuk melakukan penguatan, berikut posisi Indonesia dalam konteks ekonomi asean dan Pasific. Dalam kaitannya dan mengingat Indonesia sebagai negara dengan ekonomi terbesar di Asia Tenggara, industri manufaktur mengambil peran terbesar dari PDB yaitu 46,5 persen dari total PDB dan menjadi salah satu mesin pertumbuhan utama dari total output sebesar $24 \%$, sementara Pertambangan dan penggalian menyumbang $12 \%$, konstruksi untuk $10 \%$ dan listrik, gas dan air bersih 0,75\% dan untuk service $38 \%$ dari total PDB (perdagangan, hotel dan restoran $14 \%$; transportasi dan komunikasi
$7 \%$; keuangan, real estate dan jasa perusahaan $7 \%$, sedangkan jasa pemerintah $6 \%$ dan sisanya $15 \%$ adalah pertanian). Hal tersebut diperjelas oleh Husna (2015) bahwasanya Perekonomian Indonesia tumbuh sebesar 4,71 \% dari tahun-ketahun pada kuartal pertama 2015, ternyata turun dilaporkan dari ekspansi 5,01 \% pada periode sebelumnya. Ini adalah pertumbuhan paling lambat sejak kuartal ketiga 2009, peningkatan investasi tidak dapat menutupi penurunan lebih lanjut dalam ekspor dan perlambatan konsumsi pemerintah. Di sisi pengeluaran, pembentukan gross fixed capital tumbuh sebesar 4,36 \% dari tahun-ke-tahun, percepatan dari ekspansi 4,27\% pada kuartal sebelumnya. Konsumsi swasta naik 5,01 \%, kecepatan yang sama seperti pada periode sebelumnya, sementara belanja pemerintah meningkat sebesar 2,21 \%; melambat dari pertumbuhan 2,83\% pada kuartal ke-empat dari tahun 2014. Ekspor turun 0,53 \%, menyusul penurunan 4,53 \% pada kuartal ke-empat. Impor juga mengalami penurunan sebesar 2,20\%, menyusul pertumbuhan 3,22 \% pada kuartal bulan Desember. Lembaga non-profit yang melayani pengeluaran rumah tangga menyusut $8,25 \%$, menyusul kontraksi $0,23 \%$ pada kuartal sebelumnya. Di sisi produksi, sektor pertambangan dan penggalian dikontrak oleh 2,32 \% dari tahun-ke-tahun, menyusul ekspansi $2,22 \%$ pada kuartal bulan Desember. Sebaliknya, komunikasi dan informasi sektor mencatat tingkat pertumbuhan tahunan tertinggi $10,53 \%$, diikuti oleh jasa lainnya $8,0 \%$; keuangan dan asuransi $7,57 \%$; jasa perusahaan $7,36 \%$; pelayanan kesehatan dan kegiatan sosial $7,34 \%$; transportasi dan gudang 6,35 \%; konstruksi 6,04 \%; layanan pendidikan 5,92 \%; real estate 5,26 \%; administrasi pemerintah, pertahanan dan keamanan sosial 4,71 \%; manufaktur 3,87\%; pertanian, kehutanan 3,80 $\%$; grosir dan eceran perdagangan, sepeda dan reparasi mobil 3,66 \%; pasokan air, penanganan limbah dan daur ulang 2,27 \% dan gas dan listrik $1,55 \%$. Pada basis kuartal-ke-kuartal, ekonomi menyusut 0,18\%, menyusul kontraksi 2,06\% dari kuartal sebelumnya. Konsumsi swasta naik 0,11 persen dari pertumbuhan $0,03 \%$ pada kuartal ke-empat. Konsumsi pemerintah 48,68 persen dikontrak oleh dari pertumbuhan 43,28 $\%$ dan lembaga-lembaga non-profit yang melayani rumah tangga pengeluaran menurun 
1,19 persen dari $1,46 \%$. Investasi dikontrak oleh $4,72 \%$ dari $2,99 \%$, ekspor menurun $5,98 \%$ dari $4,32 \%$ dan impor turun $9,98 \%$.

\section{B. Indonesia and Islamic Economy Global World Organisasi Kerjasama Islam (OKI)} merupakan organisasi Islam terbesar di dunia yang beranggotan 57 negara adalah sebagian besar mayoritas Muslim dan merupakan market place yang saling berhubungan berdasarkan aktivitas keuangan modal syariah yang berkembang pesat, demografis yang masih muda dengan pilihan konsumsi keagamaan pada sektor makanan halal dan gaya hidup, perdagangan intra-OKI maupun investasi yang dipimpin oleh multilateral Bank Pembangunan Islam. Secara kolektif ekonomi ini memiliki GDP (saat ini) pada tahun 2013 dari \$ 6, 7 billion menjadi berkembang pesat pada pertumbuhan pasar global. ("2015 Top 30 Islamic Investment Growth Markets," 2015), Indonesia berada diurutan kedua setelah malaysia dan diatas UAE dengan pertumbuhan pasar dari antara 57 negara anggota OKI berdasarkan metrik sembilan. Metrik ini mencakup kategori fundamental pertumbuhan suatu negara, momentum pertumbuhan, momentum investasi dan risiko relatif suatu negara. Pasar ini diproyeksikan akan tumbuh 2015-2019 pada tingkat lebih tinggi dari seluruh dunia atau negara BRIC. (Pasar OKI 5,4\% dibandingkan seluruh dunia (ROW) 3,6\% dan 3,9\% BRICS.) ("Basics of the OIC Economies - Islamic Growth Markets Investment Outlook 2015," 2015). Mengemudi kepercayaan investasi di pasar ini adalah bonus demografi dari besar dan muda 1,6 miliar OKI pasar rakyat, tumbuh dua kali lipat tingkat populasi global - dengan kelas menengah naik dan utama pemerintah infrastruktur / diversifikasi belanja drive. Kegiatan investasi terus tumbuh dengan investasi infrastruktur greenfield besar serta dengan cepat jatuh tempo perusahaan domestik dari pasar ini. Indonesia harus puas di peringkat kedua, Indonesia lagailagi harus mengakui Malaysia yang berada di posisi teratas padahal Indonesia negara muslim paling potensial untuk investasi. Kepercayaan investasi di pasar ini adalah bonus dari demografi dari 1,6 miliar masyarakat yang ada di pasar OKI dengan pertumbuhan dua kali lipat ditingkat populasi global, naiknya kelas menengah dan infrastruktur dari diversifikasi belanja pemerintah. Kegiatan investasi terus tumbuh dengan investasi pada big greenfield infrastructure serta jatuh tempo perusahaan domestik yang cepat dari pasar ini. DinarStandard's OIC Industry Clusters Model ("TOP 10 OIC Industry Clusters," 2015) memprioritaskan 10 cluster sektor di negaranegara OKI yang memberikan kesempatan terbaik untuk strategi berbasis sektor investasi antara lain Energi, Pangan \& Pertanian, Elektronik, Travel \& Transportasi, Logam, Kimia \& Sekutu, Plastik/Karet, Tekstil, Infrastruktur \& Konstruksi, serta Produk Kesehatan \& Layanan. Di masing-masing kelompok sektor prioritas, bidang kompetensi dari pasar OKI yang berbeda di seluruh rantai nilai menyajikan peluang investasi/pertumbuhan yang unik. 10 kelompok diidentifikasi berdasarkan analisis manufaktur dan sektor jasa yang secara kolektif terkuat di pasar OKI. Prioritas ini memberikan investor pertama melihat sektor-sektor kunci dari aktivitas dan potensi pertumbuhan.

\section{Economy Ideology, SME'S and AEC}

Sistem ekonomi di dunia dipengaruhi oleh empat ideologi ekonomi yaitu sosialis, kapitalis, campuran dan islam (syariah), sedangkan Indonesia sendiri tidak menganut ke empat sistem tersebut dan menyatakan sebagai ekonomi Pancasila; walaupun pada prakteknya, sistem ekonomi pasar peran pemerintah tidak ada (Harjono, 2011). Sistem ekonomi syariah sangat berbeda dengan ekonomi sosialis, kapitalis, maupun campuran namun tidak bertentangan sesuai dengan ekonomi Pancasila (Nugrahaningsih, 2013). Ekonomi syariah bukan pula berada di tengah-tengah ke-empat sistem ekonomi tersebut maupun memihak kepada ekonomi Pancasila. Sangat bertolak belakang dengan kapitalis yang lebih bersifat individual, sosialis yang memberikan hampir semua tanggungjawab kepada warganya, campuran yang berdiri diantara kedua system (kapitalis dan sosialis) sedangkan Ekonomi Pancasila didasari pada 5 azaz. Ekonomi Islam menetapkan bentuk perdagangan serta perkhidmatan yang boleh dan tidak boleh ditransaksikan. Ekonomi dalam Islam harus mampu memberikan kesejahteraan bagi seluruh masyarakat, memberikan rasa adil, kebersamaan dan kekeluargaan serta mampu memberikan kesempatan seluas-luasnya kepada setiap pelaku usaha (Ismail, 2014). 
Sistem ekonomi Islam yang sedang tumbuh juga dapat terancam oleh pengaruh globalisasi. Namun, ekonomi Islam akan mampu berkembang dalam era globalisasi jika mampu survive memahami tututan zaman. Ekonomi Islam menghadapi berbagai tantangan seiring perkembangannya dalam era globalisasi, di antaranya adalah menumbuhkan perekonomian yang berkualitas dan upaya menjaga perekonomian agar tetap berada di jalan syar'iah (Djunaidi, 2010). Ekonomi Islam dapat dikatakan merupakan sistem ekonomi yang paling sempurna diantara sistem perekonomian yang lain. Dalam ekonomi Islam semua hal diatur berdasarkan pada AlQur'an yang sudah pasti kehaqiqiannya, serta adanya pemisahan yang jelas antara hablumminannas (hubungan antar sesama manusia) dan hablumminallah (hubungan manusia dengan Allah). Ekonomi Islam merupakan ekonomi baru dalam dunia modern yang akhir-akhir ini banyak dilirik dan dipelajari, sebab dalam ekonomi Islam tidak ada hal yang memberatkan dan merugikan seseorang. Misalnya, dalam perbankan tidak diperkenankan adanya bunga pinjaman tetapi disebut balas Jasa peminjam yang disepakti bersama dan disaksikan oleh ahli kedua belah pihak, jual-beli yang jelas, jujur, dan tidak merugikan, syirkah (syarikah atau serikat atau kongsi) antar sesama, kesemuanya telah dibuat aturan-aturan secara syar'iah. Perekonomian yang berkualitas adalah perekonomian yang dapat mensejahterakan kehidupan hajat orang banyak yang tidak hanya menghasilkan uang (pendapatan) yang tinggi atau produk yang banyak tetapi Hasil dari perekonomian dapat dirasakan secara merata oleh semua kalangan masyarakat. Dasar perekonomian Islam adalah Al Quran dan Al Hadits, sedangkan tujuanya adalah memenuhi kebutuhan manusia berdasarkan syariah dengan saling berkerjasama, berdagang, pinjam-meminjam berasaskan tolong-menolong antar sesama. Bagi Islam globalisasi bukanlah hal baru. Pada zaman Rasulullah saw, globalisasi sudah terjadi, ketika Nabi maupun para sahabat melakukan perniagaan ke luar negeri seperti ke Mesir, Syam (Siria), Irak, Yunani, Turki, dan Spanyol. Rasulullah SAW menganggap perniagaan adalah jalan mulia untuk mendapatkan rezeki. Beliau bersabda, "Ketahuilah sesungguhnya sembilan bagian rezeki itu adalah dalam perniagaan". Diriwayatkan bahwa Umar Ibnul-Khaththab R.A suatu saat melewati pasar. Di sana, beliau telah melihat bahwa kebanyakan orang yang melibatkan diri dalam perniagaan adalah orang luar dan orang awam. Keadaan ini menyedihkan beliau. Beberapa orang berkata kepada Umar R.A, "Tapi Tuan, Allah SWT telah menaklukan untuk kita banyak negara dan harta rampasan perang telah sampai ke tangan kita demikian banyaknya. Ini menyebabkan kita tidak perlu lagi berniaga untuk memenuhi keperluan". Umar R.A menjawab, "Jika kamu ingin melakuannya dan meninggalkan perniagaan sebagai tanggung jawab, kamu akan mendapatkan bahwa kaum lelaki kamu akan bergantung pada kaum lelaki mereka dan kaum perempuan kamu akan bergantung pada kaum perempuan mereka". Peringatan Umar R.A sebenarnya sudah sangat jelas: bila saja umat Islam tidak aktif dalam perniagaan, kaum non muslim lokal maupun internasional tentunya akan mendominasi ekonomi umat Islam. Inilah yang dikhawatirkan Rasulullah SAW. "Pada akhir zaman umatku akan diperebutkan sebagaimana semangkok makan yang disantap". Sahabat bertanya, "Apakah jumlah umat Islam ketika itu sedikit?" Rasulullah SAW menjawab, "Tidak, bahkan ketika itu jumlah umat Islam banyak, namun banyaknya itu bagaikan buih di lautan, karena ketika itu umat Islam menderita penyakit wahn." Sahabat bertanya, "Apakah penyakit wahn itu?" "Cinta dunia dan takut mati". Jawab Rasulullah SAW. Dalam Kaitannya, Salah satu trend isu global pada saat ini adalah munculnya sistem perekonomian syariah dan ketanggguhan UKM dalam menopang perekonomian suatu negara di banyak negara di belahan dunia. Bahkan, wacana ini menjadi project untuk menggabungkan keduanya dalam sebuah sistem perekonomian baru. Hal ini tentunya berkaitan, terutama di Indonesia yang sangat membutuhkan sebuah kepastian koridor terhadap perkembangan UMKM (Kurniawan, 2015). Menurut IFC in firstinitiative("Indonesia: Expanding Access to Islamic Finance for SMEs," 2015) , di Indonesia UKM menyumbang $90 \%$ dari angkatan kerja dan $60 \%$ dari PDB; meskipun kontribusi mereka terhadap perekonomian diperkirakan sekitar $80 \%$ dari usaha kecil dan menengah (UKM) yang underfinanced. Salah satu penyedia yang paling berkonsentrasi pada 
pembiayaan UKM adalah lembaga keuangan Islam; $80 \%$ dari semua pembiayaan mereka adalah untuk UKM. Pertumbuhan perbankan syariah di Indonesia lebih cepat, dengan hampir tiga kali lipat dari 2006 hingga April 2015 dari 456 menjadi 2.891 kanto (STATISTIK PERBANKAN SYARIAH, 2015). Perkembangan ini terkait dengan Bank Indonesia yang meluncurkan Strategy Pengembangan Perbankan Syariah Pada tahun 2008 ("Grand Strategy of Islamic Banking Market Development," 2008) yang menetapkan target untuk $5 \%$ dari seluruh aset perbankan syariah menjadi compliant dan peningkatan basis pelanggan Syariah dengan 3 juta akun sebagai fokus Pemerintah Indonesia pada perluasan akses untuk membiayai dan mempromosikan pengembangan lebih lanjut dari keuangan Islam. Hal ini dilakukan Bank Indonesia untuk memberikan bantuan teknis mendukung otoritas dalam mengembangkan keuangan Islam sebagai kendaraan untuk memperluas akses ke segmen ekonomi seperti rumah tangga dan usaha kecil. Hingga April 2015 Total Pembiayaan Bank Pembiayaan Rakyat Syariah berdasarkan Golongan Piutang/Pembiayaan dan Provinsi untuk Usaha Kecil dan Menengah sebesar Rp. 3,129,535 Trilyun, Pembiayaan Bank Umum Syariah dan Unit Usaha Syariah berdasarkan Golongan Piutang/Pembiayaan dan Provinsi sebesar Rp. 54, 812 Trilyun dan untuk Total Pembiayaan Bank Pembiayaan Rakyat Syariah berdasarkan Jenis Penggunaan dan Provinsi pada modal kerja sebesar Rp. 2,438,701 Trilyun, Investasi Rp. 994,768 Trilyun dan Konsumsi Rp. 1,892,633 Trilyun. Tujuan dari proyek ini adalah untuk meningkatkan efektivitas, efisiensi, dan jangkauan produk dan jasa keuangan Islam di Indonesia; dengan tujuan jangka panjang untuk meningkatkan akses di seluruh wilayah Asia Timur. Selain itu, pekerjaan ini dimaksudkan untuk membuat alat penilaian percontohan dengan dua komponen yang saling terkait: (i) penilaian pada akses ke keuangan Islam untuk UKM, dan (ii) kerangka strategis untuk rekomendasi kebijakan dalam meningkatkan akses terhadap pembiayaan bagi UKM melalui produk Islam dan jasa keuangan. Diharapkan bahwa alat penilaian ini dapat diterapkan di seluruh wilayah Asia Timur di negara-negara yang relevan (yaitu, Brunei, Cina, Malaysia, Filipina, Singapura, Thailand) dan negara-negara lain di seluruh dunia di mana keuangan Islam yang muncul sebagai instrumen potensial untuk memperluas akses ke segmen pasar. Setahun yang lalu, I Wayan Dipta, Deputi Bidang Pengkajian Sumberdaya UKMK, Kementerian Koperasi dan UKM RI mengatakan bahwa tantangan UKM sangat banyak. "Kami lihat persaingan makin tajam, walau sumber daya kita banyak tapi untuk memperoleh sumber daya tersebut diperlukan strategi khusus bagi para UKM. UKM juga harus menjaga dan meningkatkan daya saing sebagai industri kreatif dan inovatif. UKM juga harus meningkatkan standar, desain dan kualitas produk agar sesuai dengan ketentuan ASEAN, misalnya para UKM bisa melihat pada ketentuan ISO 26000 untukgreen product. Tantangan penting lainnya, UKM harus membuat diversifikasi output dan menjaga stabilitas pendapat usaha makro agar tidak jatuh ke kelompok masyarakat miskin. UKM juga harus memanfaatkan fasilitas pembiayaan yang ada termasuk dalam kerangka kerjasama ASEAN"("Tantangan dan Peluang UKM Jelang," 2015), ditahun yang sama Majelis Ulama Indonesia (MUI) meresmikan Pusat Inkubasi Bisnis Syariah (PINBAS) bertujuan untuk melakukan pendampingan terhadap usaha kecil menengah dengan harapan bisa meningkatkan kemampuan usaha, melalui Ketua MUI Bidang Pemberdayaan Umat, Dr Anwar Abbas, menyatakan " Kami cari penyebab usaha itu tidak maju. Tldak hanya soal modal, tetapi bisa juga promosi, pengepakan produk, dan lainnya. Juga kami akan memberi kiat-kiat meningkatkan usahanya"(Indriani, 2015), Apakah hal ini mengindentifikasi bahwa industri jasa seperti lembaga keuangan syariah khususnya multifinance syariah, asuransi syariah dan pegadaian syariah belum siap terlibat dalam ASEAN Economic Community ("IBFI Trisakti Kaji Tantangan Lks Di Pasar Bebas Asean 2015," 2015). Dari data Otoritas Jasa Keuangan, perbankan syariah membiayai usaha kecil dan menengah menerima hingga Rp 59 triliun, segmen lainnya sebesar $\mathrm{Rp} 139$ triliun. Pembiayaan konsumsi dan modal kerja masih paling tinggi yaitu berturut-turut $R p$ 79,6 triliun dan Rp 77,9 triliun. Sisanya, pembiayaan konsumsi sebesar Rp 41,7 triliun. Kepala Departemen Perbankan Syariah OJK, Edy Setiadi mengatakan ekspansi fiskal pemerintah 
diharapkan bisa memberikan ruang gerak yang memadai bagi bank syariah untuk menyalurkan pembiayaan lebih tinggi tahun 2015. OJK memproyeksi pertumbuhan pembiayaan tahun ini bisa mencapai $15 \%-18 \%$. Apakah ini Lampu kuning untuk perbankan syariah? Hal ini dikarenakan akhir tahun lalu, nilai pembiayaan yang bermasalah (NPF/non performing financing) mencapai Rp 8,6 triliun, atau sebesar $4,33 \%$ dari total pembiayaan yang tersalur per Desember 2014 sebesar Rp 199,3 triliun. Angka itu semakin dekat dengan batas maksimum NPF yang aman, yakni 5\% (Prahadi, 2015). Prabowo (2015) dalam tulisannnya memberitakan bawa Presiden Joko Widodo (Jokowi) menegaskan sektor keuangan syariah berperan dalam pembangunan, antara lain mendorong perputaran ekonomi sehingga harus terus dikembangkan. Presiden menjelaskan saat ini jumlah nasabah keuangan syariah sudah mencapai lebih 18 juta rekening. Indonesia juga merupakan negara dengan jumlah lembaga keuangan mikro terbesar di dunia, sebagian berbentuk baitul maal wa tamwil (BMT) dan koperasi jasa keuangan syariah, serta merupakan negara penerbit sukuk negara terbesar, dan satu-satunya negara yang menerbitkan sukuk ritel. Oleh karena itu, Presiden berpesan, agar keuangan syariah terus dikembangkan termasuk mendorong masyarakat memahami jenis-jenis keuangan syariah. "Kuncinya adalah membangun pemahaman masyarakat secara berkelanjutan, inovasi layanan, serta perlindungan kepada nasabah," demikian Presiden Jokowi. Lantas bagaimana posisi UMKM? Masalah UMKM relatif masih sama dari tahun ke tahun yang tetap mempersoalkan akses informasi, akses modal, akses teknologi, dan akses ke pasar. Yang menarik disini adalah pemberian KUR (kredit Usaha Rakyat) untuk UMKM yang mana hanya ada dua Bank yang melabelkan syariah yang turut serta yaitu Bank Syariah Mandiri dengan NPL KUR per Oktober 2014 sebesar 19 \% dan Bank BNI Syariah dengan NPL KUR sebesar 2,90 $\%$; dan pemerintah juga membatasi jumlah pembiayaan dari Rp. 500 juta menjadi Rp. 25 Juta ("Mulai Januari 2015 KUR Dirapikan, Sejumlah Bank Harus Mundur," 2015) walaupun pada akhirnya suku bunga kredit usaha rakyat (KUR) turun dari $22 \%$ menjadi $12 \%$ per tahun mulai akhir Juni 2015 (Fitriani, 2015). Melihat masalah ini UMKM sudah pasti tidak bisa bersaing dalam MEA dan menurut Ketua DPP LDII Prasetyo Sunaryo "Daripada bersaing, mengapa tidak melakukan kemitraan. Setiap negara memiliki kelebihan dan kekurangan masing-masing seperti sumber daya alam. Negara yang memiliki kekurangan sebenarnya bisa saling melengkapi. Untuk melakukan upaya proteksi dengan menerapkan rule of origin. Mereka membutuhkan networking seperti material yang dibutuhkan yang ada di Indonesia," (Khoir, 2015)

\section{Discussion}

Indonesia dalam rumusan kebijakan fiskalnya tertanggal 28 Mei 2015 melelui siaran persnya, Kemenkeu menyatakan ("Keterangan Pers: Kerangka Ekonomi Makro Dan PokokPokok Kebijakan Fiskal," 2015) Upaya memperkuat stimulus fiskal akan ditempuh melalui pemberian insentif fiskal untuk kegiatan ekonomi strategis, peningkatan ruang fiskal, peningkatan belanja produktif, peningkatan peran swasta, BUMN dan Pemerintah Daerah dalam percepatan pembangunan infrastruktur, serta melakukan inovasi pada instrumen pembiayaan. Jika melihat perumusan fiscal rule policy dalam APBN, Outstanding Utang masih tertinggi sebesar $60 \%$ sesuai dengan UU No 17 Tahun 2003 sedangkan sisanya terbagi dalam Anggaran Pendidikan $20 \%$, DAU $26 \%$ PDN Netto, Dana Desa $10 \%$ dan maksimal defisit 3 $\%$. Nilai utang Indonesia masih sangat besar dan tidak dapat dilunasi dalam jangka pendek, utang luar negeri Indonesia lebih dominan yaitu $99.5 \%$ sedangkan utang dalam negeri hanya $0.5 \%$. Ketergantungan utang luar negeri (ULN) Indonesia untuk membiayai defisit APBN sangat membahayakan karena semakin terbebani dengan utang pokok dan bunga, selain itu para kreditur juga akan ikut campur terhadap kebijakan ekonomi Indonesia yang bisa saja sebenarnya merugikan bangsa ini dan memberikan keuntungan bagi kreditur bangsa lain. Sementara penerimaan pajak, realisasi dan rancangan penerimaan pajak hingga triwulan I Maret 2015 meningkat sebesar 15, 32 \% jika dibandingkan dengan periode yang sama di tahun sebelumnya ("Realisasi Penerimaan Pajak Triwulan I 2015," 2015). BI Rate hingga 18 Juni 2015 masih tetap di angka $7.50 \%$. Sementara itu (Analisis Perkembangan Uang Beredar ( M2)- 
April 2015, 2015). Pertumbuhan likuiditas perekonomian M2 (Uang Beredar dalam arti luas) pada April 2015 mengalami perlambatan. Posisi M2 akhir April 2015 sebesar Rp. 4.274,9 T, atau tumbuh $14,9 \%$ (yoy), melambat dibandingkan pertumbuhan Maret 2015 yang sebesar 16,3\% (yoy). Perlambatan tersebut bersumber dari komponen M1 (Uang Kartal dan Giro Rupiah) dan Uang Kuasi (Simpanan Berjangka dan Tabungan baik dalam rupiah maupun valas serta Simpanan Giro Valuta Asing). M1 dan Uang Kuasi masing-masing tumbuh 9,0\% (yoy) dan $16,7 \%$ (yoy), melambat dari $12,2 \%$ (yoy) dan $17,6 \%$ (yoy) pada bulan sebelumnya. Berdasarkan faktor yang mempengaruhi, melambatnya pertumbuhan M2 dipengaruhi oleh turunnya pertumbuhan kredit yang disalurkan perbankan dan kontraksi operasi keuangan Pemerintah Pusat (Pempus). Pada April 2015, kredit yang disalurkan oleh perbankan mencapai Rp3.747,3 T, atau tumbuh $10,3 \%$ (yoy), melambat dibandingkan pertumbuhan bulan sebelumnya sebesar $11,1 \%$ (yoy). Sementara itu, operasi keuangan pemerintah juga mengalami kontraksi yang tercermin dari pertumbuhan tagihan bersih kepada Pempus sebesar 32,9\% (yoy), turun dari pertumbuhan bulan sebelumnya sebesar $38,2 \%$ (yoy). Suku bunga simpanan dan kredit perbankan mengalami penurunan. Pada April 2015, suku bunga deposito berjangka 1, 3 dan 6 bulan masing - masing tercatat sebesar $7,96 \%$, $8,59 \%$ dan $8,98 \%$, turun dibandingkan $8,31 \%$, $8,81 \%$ dan $9,11 \%$ pada bulan sebelumnya. Sementara itu, rata-rata suku bunga kredit juga mulai mengalami sedikit penurunan dari $12,99 \%$ menjadi $12,98 \%$, mengikuti tren penurunan suku bunga simpanan. Hal ini mungkin tidak akan mengakibatkan Asset buble yang sering berujung pada krisis menyusul meletusnya buble. Sementara Nilai tukar Rupiah terhadap Dollar hingga 26 juni 2015 masih tetap dalam kisaran Rp. 13.000 an. Laporan terakhir dari Bank Dunia menyarankan Indonesia perlu untuk mengatasi halangan-halangan struktural dalam rangka menciptakan pertumbuhan yang cepat dan struktural untuk menciptakan lapangan pekerjaan (yang berkualitas dan mendukung pengentasan kemiskinan Keterangan pemerintah atas kerangka ekonomi makro dan Pokok-pokok Kebijakan Fiskal Tahun 2016 ditanggapi baik oleh fraksi keadilan Sejahtera yang mendukung pemerintah untuk lebih memprioritaskan penerbitan sukuk negara dengan underlying proyek (projectbased sukuk). Hal ini diharapkan sekaligus dapat mendorong disiplin fiskal lebih tinggi dan berdampak langsung pada dinamika sektor riil ("Pandangan FPKS Terhadap Keterangan Pemerintah atas Kerangka Ekonomi Makro dan Pokok - Pokok Kebijakan Fiskal 2016," 2015). Pentingnya sukuk Negara sebagai pendorong pertumbuhan keuangan syariah. Saat ini Sukuk Negara bukan hanya bermanfaat sebagai acuan (benchmark) bagi sektor swasta untuk menerbitkan sukuk dan instrumen investasi bagi lembaga keuangan yang memiliki ekstra likuiditas, tetapi juga dipergunakan oleh Bank Indonesia sebagai instrumen operasi pasar terbuka. Dengan demikian, fungsi Sukuk Negara saat ini bukan hanya pada sektor fiskal sebagai instrumen pembiayaan APBN, tetapi juga berperan pada sektor moneter sebagai pengendali jumlah uang beredar. Pada Zaman Rasulllah SAW Kebijakan Fiskal dilakukan dengan Memfungsikan Baitul Maal sebagai tempat pengumpulan dana atau pusat pengumpulan kekayaan negara Islam yang digunakan untuk pengeluaran tertentu. Karena pada awal pemerintahan Islam sumber utama pendapatannya adalah Khums, zakat, kharaj, dan jizya (bagian ini akan dijelaskan secara mendetail pada bagian komponen-komponen penerimaan negara Islam). peningkatan pendapatan dan kesempatan kerja dengan mempekerjakan kaum Muhajirin dan Anshor. Upaya tersebut tentu saja menimbulkan mekanisme distrubusi pendapatan dan kekayaan sehingga meningkatkan permintaan agregat terhadap terhadap output yang akan diproduksi. Disi lain Rasullah membagikan tanah sebagai modal kerja. Kebijakan ini dilakukan oleh Rasulullah s.a.w. karena kaum Muhajirin dan Anshor keahliannnya bertani dan hanya pertanian satu-satunya pekerjaan yang menghasilkan. Kebijakan beliau sesuai dengan teori basis, yaitu bahwa jika suatu negara atau daerah ingin ekonominya maju maka jangan melupakan potensi basis yang ada di negara atau daerah tersebut. Kebijakan Pajak yang dikeluarkan pemerintah muslim berdasarkan atas jenis dan jumlahnya (pajak proposional). Misalnya jika terkait dengan pajak tanah, maka tergantung dari produktivitas dari tanah tersebut atau juga bisa didasarkan atas zonenya. 
Kebijakan Fiskal Berimbang dengan metode hanya mengalami sekali defisit neraca Anggaran Belanja yaitu setelah terjadinya "Fathul Makkah", namun kemudian kembali membaik (surplus) setelah perang Hunain). Kebijakan Fiskal Khusus dikenakan dari sektor voulentair (sukarela) dengan cara meminta bantuan Muslim kaya. Jalan yang ditempuh yaitu dengan memberikan pijaman kepada orang-orang tertentu yang baru masuk Islam serta menerapkan kebijakan insentif. Alvin (2015), populasi mayoritas penduduk indonesia beragama Islam yang merefleksikan kondisi populasi mayoritas dunia usaha di sektor UMKM, sepatutnya sistem Perbankan Syariah bisa memberikan kontribusi yang signifikan pada sektor ini. Apalagi, diyakini praktek Perbankan Syariah beserta produknya sangat sesuai dengan iklim dunia usaha sektor UMKM. Pada skala usaha yang tidak jauh berbeda dan ruang lingkup pelayanan yang juga relatif sama, dalam melayani masyarakat UMKM, BPRS ditemani oleh lembaga keuangan non-bank Syariah yang saat ini berkembang tidak kalah tingginya, yaitu Baitul Maal wa Tamwil (BMT). BMT merupakan berbadan usaha koperasi yang kini dikenal dengan Koperasi Jasa Keuangan Syariah (KJKS), yang jumlahnya kini diperkirakan telah mencapai lebih dari 110.079 unit (Hardum, 2015). Perkembangan tersebut terjadi tidak lain karena kinerja BMT yang selalu meningkat sepanjang tahunnya dan juga sistem yang dianut BMT sangat membantu masyarakat.

\section{Conclusion}

Menurut Adiwarman (2001), dalam bukunya yang berjudul Ekonomi Islam Suatu Kajian Kontemporer menyatakan bahwa peranan Organization of the Islamic Conference (OIC) dan Islamic Development Bank (IDB)mempunyai peran penting untuk dimainkan dan Ibnu Khaldun menyatakan berakhirnya maksud dari pengembangan Jika mereka tidak mempunyai kemampuan dan motivasi untuk memberikan semua usahayang dibutuhkkan untuk memperluas output dan ekspor, maka Negara Muslim tidak bisa memperoleh keuntungan penuh dari globalisasi. Pada konteks OIC dan MEA, Indonesia memiliki peran yang sangat besar dalam perjuangan penerapan ekonomi Islam, namun Indonesia juga memiliki kendala pada internal dimana ideologi perekonomian belum sepenuhnya menjalankan syariat Islam dikarenakan ideologi Indonesia adalah Pancasila namun tidak bertentangan, Indonesia juga belum melakukan praktek dari teori basis, perekonomian yang dipertahankan oleh UMKM pada saat krisis belum sepenuhnya diaplikasikan secara maksimal begitu juga dengan basis sumber daya alam yang dimiliki Indonesia belum terkelola dengan spesifik. Dalam konsep Islam, globalisasi telah ada (perdagangan Rasulullah dan bahkan bangsa Arab sebelum Rasulullah ada), Sisi penerimaan APBN terdiri atas karaj (sejenis pajak tanah), zakat, kums (pajak 1/5), jizya (sejenis pajak atas badan orang nonmuslim) dan penerimaan lain-lain (diantaranya kaffarah/denda). Dalam konsep Islam, fairness merupakan ciri sistem ekonomi. Bahkan, kata iqtisad yang sekarang banyak diterjemahkan menjadi ekonomi Islam, berasal dari kata qasd yang artinya keseimbangan (equilibrium). Islam mengatur agar persaingan di pasar dilakukan dengan adil. Setiap bentuk yang dapat menimbulkan ketidakadilan dilarang.

\section{Reference :}

2015 Top 30 Islamic Investment Growth Markets. (2015). Retrieved June 22, 2015, from

http://www.dinarstandard.com/2015-top30-islamic-inverkait stment-growthmarkets/

A. Dimyati. (2007). Ekonomi Etis : Paradigma Baru Ekonomi Islam. Jurnal Ekonomi Islam "La_Riba," I(2), 153-168.

Alamsyah, H. (2012). Perkembangan dan Prospek Perbankan Syariah Indonesia : Tantangan Dalam Menyongsong MEA 2015. Makalah Disampaikan Pada Ceramah IImiah Ikatan Ahli Ekonomi Islam (IAEI), 18(April 2012), 1-8.

Al-Rodhan, N. R., \& Stoudmann, G. (2006). Definitions of globalization: $A$ comprehensive overview and a proposed definition. Program on the Geopolitical Implications of Globalization and Transnational Security, 6, 1-21.

Alvin. (2015). Peran Baitul Maal Wa Tamwil dalam Pemberdayaan UMKM. Retrieved June 27, 2015, from 
http://nusantarabersatu.com/peran-baitulmaal-wa-tamwil-bmt-dalam-

pemberdayaan-usaha-mikro-kecil-danmenengah-umkm/

Analisis Perkembangan Uang Beredar ( M2)April 2015. (2015) (pp. 1-5). Jakarta.

Retrieved from

http://www.bi.go.id/id/publikasi/perkemb angan/Default.aspx

Ariawan. (2012). Perjanjian Perdagangan Bebas Dalam Era Liberalisasi Perdagangan : Studi Mengenai ASEAN-China Free Trade Agreement (ACFTA) Yang Diikuti Oleh Indonesia. Universitas Indonesia.

Asean Economic Community Blueprint. (2008). Jakarta. Retrieved from www.asean.org

Basics of the OIC Economies - Islamic Growth Markets Investment Outlook 2015. (2015). Retrieved June 22, 2015, from http://www.dinarstandard.com/basics-ofthe-oic-economies/

Basir, A., \& Mamat, A. (2012). Dakwah kepada Masyarakat Bukan Islam Menerusi Interaksi. Jurnal Islam Dan Masyarakat Kontemporari, 5, 77-89.

Berger, P. L., \& Huntington, S. P. (Eds). (2003). Many globalizations: Cultural Diversity in the Contemporary World. Oxford University Press.

Budianto, A. (2013). PEMBAHARUAN KITAB HUKUM DAGANG INDONESIA : Antara Kodifikasi , Kompilasi dan Konsolidasi. Jurnal Ilmu Syari'ah Dan Hukum "AsySyir'ah," 47(2).

Chapra, M. U. (1992). Islam and the Economic Challenge. Leicester: Islamic foundation.

Chapra, M. U. (2001). Islamic Economic Thought and the New Global Economy. Islamic Economic Studies, 9(1), 1-16.

Cizakca, M. (2007). Democracy, Economic Development and Maqasid Al-Shari'ah. Review of Islamic Economics, 11, 101-118.

Cowen, D. (2015). Outlook Ekonomi Regional dan Indonesia (pp. 1-3). Washington D.C.

Delanty, G., \& Rumford, C. (2007). Political globalization (pp. 414-428). The Blackwell Companion to Globalization.
Deny, S. (2013). 8 Tantangan Ekonomi Indonesia di Masa Depan. liputan6.com. TenggerangBanten. Retrieved from http://bisnis.liputan6.com/read/745485/8tantangan-ekonomi-indonesia-di-masadepan

Deorukhkar, S., \& Xia, L. (2015). Indonesia 's Q1 GDP growth falters to $4.7 \%$ y / y - A wake up call for Jokowi ? Asia Flash, 4-6.

Retrieved from www.bbvaresearch.com

Djunaidi. (2010). Peluang Dan Tantangan Pengembangan Pemikiran Islam Dewasa Ini. Media Akademika, 25(4).

Fitriani, F. F. (2015). Resmi , Bunga KUR Turun Jadi $12 \%$. Retrieved June 26, 2015, from http://industri.bisnis.com/read/20150618/ 87/444587/resmi-bunga-kur-turun-jadi-12

Grand Strategy of Islamic Banking Market Development. (2008). Directorate of Islamic Banking Bank Indonesia. Jakarta, Indonesia. Retrieved from www.bi.go.id

Hardum, S. E. (2015). Dipacu, Modernisasi Koperasi Simpan Pinjam "Online." Retrieved June 28, 2015, from http://www.beritasatu.com/ekonomi/2446 37-dipacu-modernisasi-koperasi-simpanpinjam-online.html

Harjono, D. K. (2011). Konsep Pembangunan Hukum dan Perannya Terhadap Sistem Ekonomi Pasar. Jurnal Hukum, 18(4), 564584.

Harvey, D. (1990). Between Space and Time: Reflections on the Geographic Imagination. Annals of the Association of American Geographers, 80, 418-434.

Hasnita, N. (2012). Politik Hukum Ekonomi Syari' ah. Jurnal Hukum Pidana Dan Politik Hukum "Legitimasi," 1(2), 259-275.

Husna, R. (2015). Indonesia GDP Growth Weakest in 6 Years. Retrieved June 22, 2015, from http://www.tradingeconomics.com/indone sia/gdp-growth-annual

IBFI Trisakti Kaji Tantangan Lks Di Pasar Bebas Asean 2015. (2015). Retrieved June 26, 2015, from http://beta.seputarukm.com/ibfi-trisakti- 
kaji-tantangan-lks-di-pasar-bebas-asean2015/

Inda, J. X., \& Rosaldo, R. (2002). The Anthropology of Globalization: A Reader. Media (p. 498). Blackwell Publishers Ltd.

Indonesia : Expanding Access to Islamic Finance for SMEs. (2015). Retrieved June 24, 2015, from https://www.firstinitiative.org/node/151

Indriani. (2015). ANA to Tokyo from 535USD Tourism New Zealand. Retrieved June 26, 2015, from http://www.antaranews.com/berita/45452 8/mui-resmikan-pusat-inkubasi-bisnissyariah

Ismail, A. G. (2014). Between Free Market and State Capitalism: How Islamic Economics System Shape the Future Global Economy? (No. 1434-07). Jeddah-Kingdom of Saudi Arabia. Retrieved from http://www.irti.org/irj/portal/anonymous? NavigationTarget=navurl://259079a26b2a2 $7 b c f c 5 e 87 a 8 d 5 a c 8 f c a$

Ja'far, A. K. (2010). Pengaruh globalisasi terhadap pembangunan hukum ekonomi di indonesia. Jurnal Asas, 2(2), 15-27.

Karim, A. A. (2001). Ekonomi Islam: suatu kajian temporer. Gema Insani.

Kersten, C. (2012). Shari' a Politics: Islamic Law and Society in the Modern World. Middle Eastern Studies, 48(October 2014), 669672. doi:10.1080/00263206.2012.683605

Keterangan Pers: Kerangka Ekonomi Makro Dan Pokok-Pokok Kebijakan Fiskal. (2015). Kementerian Keuangan Republik Indonesia. Jakarta, Indonesia. Retrieved from http://www.kemenkeu.go.id/sites/default/ files/KP_KEMPPKF_280515.pdf

Khoir. (2015). Hadapi Masyarakat Ekonomi ASEAN, Bermitra atau Bersaing? Retrieved June 26, 2015, from http://balikpapan.Idii.or.id/2015/06/hadapi -masyarakat-ekonomi-asean-bermitraatau-bersaing.html

Khotimah, K. (2009). Islam dan Globalisasi : Sebuah Pandangan tentang Universalitas Islam. Komunika, 3(1), 114-132. Retrieved from

http://ejournal.stainpurwokerto.ac.id/inde x.php/komunika/article/view/118/92

Kuran, T. (1986). The Economic System in Contemporary Islamic Thought: Interpretation and Assessment. International Journal of Middle East Studies, 18(2), 135-164. doi:10.1017/S0020743800029767

Kurniawan, G. (2015). Ikatan Saudagar Muslim Dorong UMKM Berbasis Syariah. Retrieved June 24, 2015, from http://industri.bisnis.com/read/20140913/ 87/257054/ikatan-saudagar-muslimdorong-umkm-berbasis-

Mahendra, D. I. (2015). Pengusaha Harapkan Perombakan Kabinet. Media Indonesia, p.

2. Jakarta. Retrieved from http://pmlseaepaper.pressmart.com/medi aindonesia/PUBLICATIONS/MI/MI/2015/06 /25/ArticleHtmls/Pengusaha-HarapkanPerombakan-Kabinet25062015002020.shtml?Mode=1

Mashdurohatun, A. (2011). Tantangan Ekonomi Syariah dalam Menghadapi Masa Depan Indonesia di Era Globalisasi. Jurnal Dinamika Hukum, 11.

Mulai Januari 2015 KUR Dirapikan, Sejumlah Bank Harus Mundur. (2015). Retrieved from http://sharia.co.id/2014/12/16/mulaijanuari-2015-kur-dirapikan-sejumlah-bankharus-mundur/

Nrm. (2014, November). Janji-janji Jokowi di Hadapan Investor Dunia. liputan6.com. Beijing-China. Retrieved from http://bisnis.liputan6.com/read/2131578/j anji-janji-jokowi-di-hadapan-investor-dunia

Nugrahaningsih, W. (2013). Kesesuaian Hukum Kontrak Syariah Di Indonesia Terhadap Pancasila Sebagai Sumber Hukum Di Indonesia. Jurnal Ilmiah Teknologi Informasi Dan Komunikasi "Duta.Com," 4(1). Retrieved from http://library.stmikdb.ac.id/

Pandangan FPKS Terhadap Keterangan Pemerintah atas Kerangka Ekonomi Makro dan Pokok Pokok Kebijakan Fiskal 2016. 
(2015). Retrieved June 27, 2015, from http://www.fraksidpr.pks.id/content/aleg/f raksi/pandangan-fpks-terhadapketerangan-pemerintah-atas-kerangkaekonomi-makro-dan

Pangiuk, A. (1997). Kepemilikan Ekonomi Kapitalis Dan Sosialis (Konsep Tauhid Dalam Sistem Islam). Nalar Figh, 1-19.

\section{Peran Ekonomi Syariah Dalam Kebijakan} Ekonomi Nasional Untuk Menghadapi AEC. (2014). Indonesia. Retrieved from http://www.ekon.go.id/

Prabowo, P. H. (2015). Presiden Jokowi: Sektor keuangan syariah berperan dalam pembangunan. Retrieved June 26, 2015, from http://www.antaranews.com/berita/50145 6/presiden-jokowi-sektor-keuangansyariah-berperan-dalam-pembangunan

Prahadi, Y. Y. (2015). Pembiayaan Bermasalah Tinggi, Bank Syariah Hati-Hati. Retrieved June 26, 2015, from http://swa.co.id/businessstrategy/management/pembiayaanbermasalah-tinggi-bank-syariah-hati-hati

Pryor, F. L. (1985). The islamic economic system. Journal of Comparative Economics, 9, 197223. doi:10.1016/0147-5967(85)90039-3

Realisasi Penerimaan Pajak Triwulan I 2015. (2015). Retrieved June 27, 2015, from http://www.pajak.go.id/content/realisasipenerimaan-pajak-triwulan-i-2015

Regional Economic Outlook Asia and Pacific : Stabilizing and Outperforming Other Regions. (2015). Washington, D.C.: International Monetary Fund.

Rombak Kabinet Bangkitkan Pasar. (2015). Retrieved June 25, 2015, from http://www.mediaindonesia.com/editorial /view/459/Rombak-Kabinet-BangkitkanPasar/2015/06/25

Sattar, Z. (1989). Interest-Free Economics and the Islamic Macroeconomic System. Pakistan Economic and Social Review, 27(2), 109-138. doi:10.2307/25825037

Sharif, M. (2003). Application of Islamic Economic System in a Contemporary
Economy: An Illustration with Poverty and Inequity in the USA. Humanomics, 19, 4154. doi:10.1108/eb018888

State of the Global Islamic Economy 2014 - 2015 Report. (2015).

STATISTIK PERBANKAN SYARIAH. (2015) (p. 2). Jakarta. Retrieved from http://www.ojk.go.id/data-statistikperbankan-syariah

Stavrev, E., Vesperoni, E., Saxena, S., Bang, E., Hong, A. Y., \& lonescu, G. (2015). GLOBAL PROSPECTS AND POLICY CHALLENGES : G20 Finance Ministers and Central Bank Governors Meeting. Istambul-Turkey.

Sufiarina. (2011). Politik hukum ekonomi syariah di indonesia. Jurnal Supremasi Hukum, $I V(2)$.

Tantangan dan Peluang UKM Jelang. (2015). Retrieved June 26, 2015, from http://swa.co.id/businessstrategy/tantangan-dan-peluang-ukmjelang-mea-2015

TOP 10 OIC Industry Clusters. (2015). Retrieved June 23, 2015, from http://www.dinarstandard.com/top-oicindustry-clusters/

Undang-Undang Republik Indonesia Nomor 3 Tahun 2006 Tentang Perubahan Atas Undang-Undang Nomor 7 Tahun 1989 Tentang Peradilan Agama, Pub. L. No. 3 TAHUN 2006 (2006). Indonesia: http://www.setneg.go.id/.

Undang-Undang Republik Indonesia Nomor 50 Tahun 2009 Tentang Perubahan Kedua Atas Undang-Undang Nomor 7 Tahun 1989 Tentang Peradilan Agama, Pub. L. No. 50 Tahun 2009 (2009). Indonesia. Retrieved from http://www.setneg.go.id/

World Economic Outlook: Uneven GrowthShort- and Long-Term Factors. (2015). Washington: International Monetary Fund.

Zulaikha, S. (2013). Pengaruh Globalisasi Ekonomi Terhadap Hukum Ekonomi Islam Di Indonesia. Jurnal Adzkiya, 1(1), 1-14. 